\title{
ТЕОРИЯ ПРИНЯТИЯ ПОЛИТИЧЕСКИХ РЕШЕНИЙ В СТРУКТУРЕ СОЦИАЛЬНЫХ И УПРАВЛЕНЧЕСКИХ ДИСЦИПЛИН
}

\author{
А.А. Дегтярев
}

Дегтярев Андрей Алексеевич, кандидат философских наук, профессор МГИМО (У) МИД РФ, доцент Московской школы социальных и экономических наук.

Сложилась ли теория принятия политических решений (ТППР) в самостоятельную дисциплину, каковы ее внутренняя структура и место в комплексе социальных и управленческих наук? Эти вопросы тем более актуальны, что немало специалистов считают указанное направление лишь некой междисциплинарной областью исследований. Но прежде чем подойти к ответам на них, следует, на наш взгляд, вкратце остановиться на исторических предпосылках появления ТППР и ее генезисе. Ведь многие теоретические идеи и практические принципы принятия решений были сформулированы за столетия (если не тысячелетия) до того, как рассматриваемая теория начала институционализироваться в относительно автономную сферу знания_1.

\section{Становление и развитие теории принятия политических решений}

\section{Теоретические истоки}

Вопросы принятия государственных решений, подготовки разумных законов и других актов издавна привлекали внимание философов_2_. Однако, несмотря на тот весомый вклад, который внесли в становление теории государственного управления Платон, Каутилья, Шан Ян и другие политические мыслители древности, первенство в разработке специальной концепции принятия решений все же по праву принадлежит Аристотелю. Именно он сформулировал исходный категориальный аппарат и разработал базовый концепт, описывающий принятие решений [см. Аристотель 1984: 95, 172]. В своем анализе Стагирит исходил из категорий “рассудительность” (phronesis) и “сознательный выбор” (proairesis). При этом он отталкивался от представления о том, что существуют два типа мыслительных способностей человека: теоретическая мудрость и практическая рассудительность, на которых строятся, соответственно, фундаментальное и прикладное знание. Рассудительность связана с практической деятельностью людей (в т.ч. с государственным управлением), и ей должны отвечать человеческие поступки, базирующиеся на истинных суждениях и ориентированные на достижение утилитарной пользы в форме общественного или личного блага.

Чем же рассудительность в государственном управлении отличается от прочих ее разновидностей? Политическое знание (в данном аспекте) выступает в двух ипостасях: “одна как управляющая представляет собой законодательную (науку), другая как имеющая дело с частными (вопросами) носит общее название государственной науки, причем она предполагает поступки и принимание решений, ибо что решено голосованием (народного собрания) как последняя данность (to eskhaton) осуществляется в поступках" [Аристотель 1984: 180-181]. Другими словами, принятие государственных решений основывается на практическо-политическом (т.е. прикладном, в современном понимании) типе знания, включающем в себя постановку целей (то или иное благо) и способы их реализации (поступки, действия).

Вторая базовая категория - “сознательный выбор” — отражает известную произвольность и неопределенность человеческой деятельности, направленной на поиск путей достижения уже обозначенных целей. “Предмет решения”, как отмечает Аристотель, касается не столько конечных целей, сколько средств их реализации. Поскольку человек является субъектом действий (поступков), “решение относится к тому, что он сам осуществляет в поступках, поступки же совершаются ради чего-то другого” [см. Аристотель 1984: 103]. Таким образом, принятие государственных решений, по Аристотелю, есть 
мыслительно-практическая деятельность и прикладная наука, ориентированные, во-первых, на сознательный и разумный выбор средств, адекватных сформулированным целям, а во-вторых, на выявление оптимальных и возможных действий (поступков) для достижения таких целей в условиях неопределенности ситуации и произвольности свободного выбора.

Вопросы рационального и эффективного принятия государственных решений довольно интенсивно исследовались политическими мыслителями Возрождения (Н.Макиавелли, Ж.Боден и др.) и Просвещения (Т.Гоббс, Б.Спиноза, Ж.Ж.Руссо и др.) Можно выделить ряд наиболее активно разрабатывавшихся сюжетов: виды государственных актов (Гоббс), роль советников и советов при правителях (Гоббс, Макиавелли), особенности голосования в представительных органах и народных собраниях (Спиноза, Руссо), учет ресурсов и факторов социальной обстановки при принятии решений (Боден). В работах упомянутых авторов содержится немало идей, не потерявших своей актуальности и сегодня.

Теоретическое осмысление данной проблематики, разумеется, велось и в дальнейшем. Систематический компаративный анализ достигнутого в этой области еще ждет своего научного воплощения [см. Нойштадт 1997]. В пределах, ограниченных объемом и предметом данной работы, я остановлюсь лишь на характеристике современного этапа развития рассматриваемой теории.

\section{Современный этап}

Во второй половине XX в. дифференциация социальных и гуманитарных наук продвинулась уже довольно далеко. В самостоятельную отрасль знания выделилась политическая наука, государственное управление стало преподаваться во многих западных университетах в качестве отдельной субдисциплины. Именно тогда сложились предпосылки, позволившие ТППР оформиться в особую дисциплину — теорию принятия политических решений, входящую в политико-управленческие науки (policy sciences). Последний термин был введен в 1930 - 1940-е годы одним из основателей Чикагской школы политического бихевиоризма Г.Лассуэллом. Согласно его определению, “научная дисциплина может быть отнесена к политико-управленческим наукам, если она разъясняет процесс принятия политических решений (process of policy making) в обществе или же обеспечивает необходимыми данными разработку рациональных способов разрешения политико-управленческих вопросов” [Lasswell 1948: 120].

По мнению Лассуэлла, концептуальное оформление политико-управленческих наук было в огромной мере стимулировано глубоким кризисом, связанным с двумя мировыми войнами, тем более что немалую роль в возникновении последних сыграли непродуманность и необоснованность политических решений лидеров многих держав мира [Lasswell 1948: 121]. Ученый называет и другие факторы, способствовавшие институционализации политико-управленческих наук. Прежде всего, это практические нужды сохранения и совершенствования западной демократии, требующие оптимизации государственного управления и взаимодействия органов власти с другими общественными институтами, а также интеллектуального обеспечения рационального достижения государственных целей при ограниченных ресурсах. Кроме того, внутри самих социальных наук созрела потребность в интеграции и преодолении традиционных барьеров, что позволило бы не только устранить дублирование проблематик и заполнить “белые пятна” на стыках дисциплин, но и высвободить интеллектуальные силы для приложения научных результатов к практической политике, в т.ч. к выработке долгосрочных стратегий.

Итак, во второй половине XX в. в США складывается новая область знания - политическое управление, постепенно развертывающаяся в целый комплекс политико-управленческих дисциплин. Этот сложный научный комплекс образовался на стыках предметных полей трех “кластеров” социально-гуманитарных дисциплин: (1) социально-политического (политическая, социологическая и экономическая науки); (2) когнитивно-эпистемологического (философия, психология и информационно-коммуникативные исследования) и (3) менеджериального (государственное администрирование, организационная теория, общий менеджмент, военная наука). Другими словами, произошел интеграционный синтез различных сфер социально-гуманитарного знания, к которому со временем добавились математические и кибернетические исследования и методы обработки информации. Пионерами этого междисциплинарного синтеза конца 1940 — 1950-х годов стали Г.Лассуэлл и Г.Саймон. Первый (вместе с Д.Лернером) подготовил новаторскую работу “Политико-управленческие науки” [Lasswell, Lerner 1951], второй опубликовал монографию “Административное поведение: исследование процессов принятия решений в административных организациях”, принесшую ему Нобелевскую премию [Simon 1947]. 
Какие же методологические подходы и концептуальные разработки создали предпосылки для подобной интеграции знаний в новое научное направление, в частности, для институционализации ТППР и прикладного политического анализа? Начнем с “кластера” дисциплин, связанных с социально-политическими науками. В рамках политологии импульс к изучению принятия государственных решений возник во многом вне круга традиционной для данной дисциплины проблематики. На это обращает внимание Ч.Линдблом, который замечает, что “процесс принятия политических решений не походит на такие стандартные для политической науки области, как сравнительное государствоведение, международные отношения или история политической мысли” [Lindblom 1968: 2]. Новые модели исследования государственной политики опирались главным образом на бихевиористский и системный подходы, которые начали складываться еще до второй мировой войны и изначально имели междисциплинарный характер. Прежде всего это относится к бихевиористской теории политического поведения, разрабатывавшейся Лассуэллом и содержавшей немало элементов, взятых из психологии и социологии (мотивы и установки, интересы и ценности людей, принимающих решения). Следует также напомнить, что в начале 1950-х годов вышли работы Т.Парсонса “Социальная система” (1951) и Д.Истона “Политическая система” (1953), где были сформулированы основы системно-функционального подхода к интерпретации циклов государственной политики и процессов принятия решений. Наконец, большую роль в развитии политико-управленческого анализа сыграло заимствование методов макро- и микроэкономических исследований (“затраты — выгоды”, “затраты — эффективность” и др.), активно применяющихся при оценке эффективности госрешений по сей день.

Своеобразным катализатором исследований принятия государственных решений стал когнитивно-эпистемологический “кластер”. Формирование американской концепции принятия решений проходило под воздействием философии прагматизма и инструментализма, особенно работ одного из основателей Чикагской школы, в стенах которой учились или работали Лассуэлл и Саймон, - Дж.Дьюи [см. Simon 1944, Оберемко 1994]. Именно последний был автором прагматической концепции “решения проблем” (problem solving), которая впоследствии легла в основу моделей политико-управленческого цикла (policy cycle). Кроме того, при построении теории принятия решений ее разработчики активно задействовали психологические подходы: психоаналитический (Лассуэлл) и когнитивный (Саймон). Влиянию “психологической среды” на выбор решения посвящена целая глава в уже упоминавшейся книге Саймона. В той же книге Саймон поднимает вопрос об информационном обеспечении принятия административных решений и рационализации обработки информации [см. Simon 1947].

Третий по счету (но не по значению) “кластер” дисциплин, внесших свой вклад в формирование теории принятия решений, связан с менеджериальными науками. К середине XX в. в США уже активно преподавались государственное администрирование (в школах госуправления) и курсы общего менеджмента (в школах бизнеса). В своих трудах 1940-1960-х годов Саймон последовательно обосновывал идею создания административной науки (administrative science) как универсально-общей теории принятия решений, принципы которой были бы применимы и в государственном управлении, и в руководстве бизнес-структурами [см., напр. Simon 1960]. Позднее, в 1980-1990-х годах, широкое распространение на Западе получила концепция так наз. нового госуправления (new public management), сторонники которой по сути дела исходили из близкой Саймону идеи адаптации к работе государственных органов передовых технологий, заимствованных из бизнес-менеджмента.

Существенное влияние на становление ТППР оказала организационная наука, имеющая комплексную структуру и занимающаяся теоретическими, социологическими и психологическими проблемами организаций. Эта субдисциплина начала складываться в 1930-1950-е годы главным образом в рамках корпоративного управления, а затем проникла и в государственный сектор [см. Henry 1995; Lawtan, Rose 1994]. Наконец, в аналитический арсенал рассматриваемой теории попадают активно использовавшиеся в военном управлении периода второй мировой войны методы исследования операций.

Если попытаться в общих чертах провести периодизацию пока совсем короткой истории становления современной ТППР, то, пожалуй, можно выделить три крупных этапа: (1) формирование исходных подходов и концептов (конец 1940-х — вторая половина 1960-х годов); (2) институционализация направления как университетской учебной и научной дисциплины (конец 1960-х - 1970-е годы); 3) развитие теоретических и эмпирических направлений “вширь” и “вглубь”, дифференциация и специализация направлений и подотраслей (1980-1990-е годы).

На первом этапе Лассуэлл ставит вопрос о необходимости выделения политико-управленческих наук в 
особую отрасль социального знания и публикует ряд книг, посвященных обоснованию и пропаганде этой идеи [см. Lasswell, Lerner 1951; Lasswell 1956, 1970]. В так наз. политико-управленческое движение (роlicy movement) вовлекаются многие ученые: политологи, экономисты, психологи, правоведы и др. [см. Snyder 1958, Sorensen 1963, Allison 1971]. Идет разработка подходов и обсуждение теоретических концептов. Так, на рубеже 1950-1960-х годов на страницах журнала “Public Administration Review” проводится дискуссия относительно таких моделей принятия политических решений, как “рационализм”, “инкрементализм” и “смешанное сканирование”, в которой принимают участие Саймон, Линдблом, Дрор, А.Этциони и другие известные ученые. Начинают преподаваться пробные курсы, издаваться журналы и первые учебные пособия, выходит учебник Линдблома “Процесс принятия политических решений” [Lindblom 1968]. Bce это создает определенные предпосылки для утверждения нового научного направления в качестве академической дисциплины.

В ходе второго и третьего периодов получает официальное признание ряд политико-управленческих дисциплин (“политический анализ”, “принятие политических решений” и “государственная политика”), которые включаются в программы большинства факультетов политической науки и изучаются в школах государственного администрирования. По данной проблематике защищаются сотни диссертаций, публикуются тысячи научных трудов. Постепенно складывается внутренняя специализация ученых. Создаются работы, посвященные отдельным фазам политико-управленческого цикла (формирование решения, его реализация, оценка результатов и пр.), анализу сетей в МППР, специфике принятия решений в различных сферах (в экономике, образовании, обороне и пр.). Появляется множество научных журналов по государственной политике и принятию решений, в т.ч. “Журнал политического анализа и менеджмента”. В 1972 г. создается Организация политико-управленческих исследований (Policy Studies Organization), а в 1979 г. - Ассоциация политического анализа и менеджмента (Association for Public Policy Analysis and Management), насчитывающая сегодня 80 коллективных и около 2 тыс. индивидуальных членов.

С течением времени практически полной монополии США на проведение исследований по публичной политике и ее преподавание приходит конец. Академические курсы по указанной проблематике появляются в Европе (в Великобритании, Франции, Германии, Нидерландах, странах Скандинавии и др.). Начинают выходить соответствующие журналы (например, “Journal of European Public Policy”, “Journal of Public Policy” и др.). Сегодня политико-управленческие дисциплины преподаются в высших учебных заведениях Азии, Африки, Австралии и Латинской Америки, хотя при этом “гегемония” США все же ощущается. Постепенно они проникают и в посткоммунистические страны, в т.ч. в российские университеты, где уже введены курсы по “государственной политике и управлению” и “политическому анализу и прогнозированию”.

\section{Базовые характеристики теории принятия политических решений}

\section{Предметное поле}

Попытки очертить предметное поле ТППР предпринимались с самого момента зарождения дисциплины. Обосновывая правомерность выделения политико-управленческих наук в особую отрасль социального знания, Лассуэлл следующим образом определял их предмет: “Политико-управленческие науки включают в себя: (1) методы, с помощью которых исследуется политико-управленческий процесс; (2) научные результаты исследований и (3) разработки в рамках данных дисциплин, создающие наиболее важный базис для востребованных жизнью аналитических технологий” [Lasswell 1951]_3_. Вместе с тем ученый указывал на ряд специфических черт, присущих названной совокупности дисциплин. Во-первых, эти дисциплины занимаются изучением всех фаз политико-управленческого процесса; они “имеют отношение к объяснению процесса принятия решений и исполнения решений, а также к аккумуляции данных и их интерпретации, обеспечивающих разрешение соответствующих политических проблем в определенный период” [Lasswell 1951: 14]. Во-вторых, рассматриваемый комплекс дисциплин имеет двуединую цель: с одной стороны, получение научного знания о политико-управленческом процессе как таковом, т.е. выяснение его внутренних механизмов, а с другой - накопление знаний о практическом решении реальных проблем (knowledge in the policy process), встающих перед политиками и администраторами, и выработка соответствующих рекомендаций [Lasswell 1970: 13; см. также Hill 1997: 2]. В-третьих, политико-управленческие науки ориентированы на ситуационный и комплексный анализ политической проблемы, а не на сегментированный и предметно-дифференцированный подходы. И, наконец, в-четвертых, они носят междисциплинарный и полиметодологический характер.

Множество рабочих дефиниций предмета теории принятия решений было предложено И.Дрором. Так, в 
частности, он отмечает, что политико-управленческая наука есть академическая дисциплина, ориентированная на постижение “процессов, благодаря которым и происходит воспроизводство и развитие человеческого общества и самих людей, а именно процессов и систем принятия решений, систем анализа и проектирования, а также механизмов комплексной поддержки и интеллектуального обеспечения принятия этих самых решений” [Dror 1989: 7]. При этом исследователь выделяет в ней два основных элемента: “отраслевое управленческое знание” (policy-issue knowledge), связанное с отдельными сферами управленческого воздействия (политика в области здравоохранения или, скажем, этнонациональных отношений, внешняя политика и т.д.), и собственно “знание, касающееся принятия решений” (policy-making knowledge), которое имеет дело с общими механизмами государственной политики, включая организационную структуру госаппарата, координацию операциональных взаимодействий между его подразделениями, состав управленческого персонала и, наконец, технологии обработки и анализа информации, позволяющие совершенствовать процессы управления [Dror 1989: 8].

Исходя из приведенных выше характеристик политико-управленческих наук, можно дать сводное определение предмета ТППР:

Теория принятия политических решений - это политико-управленческая наука, связанная с изучением на мультидисциплинарной основе механизмов и закономерностей публично-государственной политики, а также с разработкой принципов и методов подготовки, принятия и осуществления публично-государственных решений, составляющих политический курс, для научно-интеллектуального обеспечения эффективности государственного управления в определенных проблемных ситуациях.

Из предложенной рабочей формулировки вытекает, что ТППР имеет и фундаментальный, и прикладной аспекты, включает в себя исследования, ориентированные как на “анализ-сути-политики”, так и на “анализ-ради-политики” [см. Дегтярев 1996].

Теория принятия решений выступает своего рода связующим звеном между фундаментальным и прикладным знанием. Трудно бывает полностью отделить предварительное изучение природы и системы принятия решений, скажем, в МИД РФ, сопоставление его корпоративных традиций и ведомственных процедур с принятыми в аналогичных структурах других демократических стран (что само по себе может вменяться в задачи сравнительной политологии) от подготовки практических рекомендаций для проведения очередной модернизации аппарата данного министерства в соответствии с меняющимися условиями и задачами государственной политики. М.Хилл по этому поводу замечает, что, хотя само исследование политико-управленческого процесса считается “более фундаментальной” дисциплиной, на которую должны опираться практически ориентированные разработки в области политического анализа, было бы неверным переоценивать подобное их различие [Hill 1997: 6]. Отсюда следует, что, поскольку объект анализа в фундаментальном и прикладном исследовании принятия решений совпадает, ТППР находится на стыке фундаментальной политической теории (принятие решений в механизме власти и управления) и сравнительной политологии (сравнительные исследования публичной политики и государственного управления), с одной стороны, и прикладной политологии (политический анализ, разработка технологий политического менеджмента и управленческого воздействия) - с другой.

Какие же дисциплины подготовили базу для развития ТППР? На междисциплинарный характер этой теории еще в 1940-1960-е годы обращали внимание Саймон, Лассуэлл, Дрор и Линдблом. Выше уже говорилось, что междисциплинарный синтез знаний вокруг формировавшейся в середине XX в. теории принятия решений, включая заимствование концептов и методов разных наук, был подготовлен процессами, обусловленными становлением и распространением бихевиористского, менеджериального и системного подходов. Несколько позднее он был дополнен освоением новых методов анализа информации, связанных с внедрением кибернетического подхода и компьютерной техники. Одним из первых на эти “горизонтальные линии” интеграции указал Саймон, использовавший при конструировании своей теории административных решений элементы, взятые из психологии и экономики, политологии и социологии, организационной и информационной наук. Когда нобелевского лауреата спросили, к какой из социальных наук — к социологии или психологии - принадлежит концепция принятия решений, он ответил, что такая постановка вопроса столь же некорректна, как попытка выяснить, относится ли молекулярная биология к биологии или к химии. “В каждом из взятых случаев корректным был бы ответ: к обеим” [Simon 1997:24].

Детальный разбор вопроса о междисциплинарной основе политико-управленческого знания предпринял Дрор, выделивший 23 научные дисциплины, составляющие фундамент политического управления. Эти 
дисциплины были подразделены им на четыре группы: (а) традиционные — история, право и др.; (б) социальные - психология, социология, политическая и экономическая наука и др.; (в) новые междисциплинарные области - менеджмент, системный анализ, исследования конфликтов и коммуникаций и др.; (г) так наз. абстрактные науки - логика и семантика, философия и этика, математика и статистика [Dror 1989: 320].

Особое место в этом междисциплинарном комплексе занимает политическая наука, представляющая собой базовую площадку для синтеза всевозможных идей и подходов, концептов и методов, связанных с анализом принятия политических решений. Линдблом перечисляет ключевые вопросы, которые в ракурсе своих предметов обычно ставят представители различных наук. Психологов интересует, как человек использует свое сознание при решении проблем; экономистов - как сделать такой выбор, чтобы получить максимум выгоды; философов - каким образом человек выбирает наиболее ценное для него; специалистов по государственному администрированию - какими способами людям удается заставить целую организацию служить их целям. Обращаясь к роли политологов, которые объединяют вышеприведенные и некоторые другие вопросы в единый комплекс, Линдблом утверждает, что главным в государственной политике является вопрос о природе “политических решений” (political decisions) [Lindblom 1968: 3]. Другими словами, центральный вопрос ТППР касается отношений по поводу власти: что и как получают от тех или иных решений властвующие и подвластные, а что - общество и государство в целом? Этот ключевой вопрос политики и образует то измерение дискурса, в котором должен осуществляться междисциплинарный синтез концептов и подходов, формирующих теоретико-методологическое содержание ТППР как самостоятельной научной дисциплины.

\section{Структура}

Существует несколько критериев, на основе которых можно структурировать предметное поле ТППР. Первый из них вытекает из уже зафиксированной нами двойственности данной дисциплины, ориентированной и на познание природы и механизмов государственной политики, и на приложение этих знаний в конкретных технологиях проектирования и продвижения политических решений в практику государственного управления. Как отмечается в “Энциклопедии политико-управленческих исследований”, изучение государственной политики предполагает и фундаментальные, и прикладные исследования, которые, правда, пока еще весьма слабо связаны между собой. Это объемное “предметное поле вбирает в себя, с одной стороны, теории, описывающие и объясняющие политико-управленческий процесс, а с другой - прескриптивные теории, посвященные тому, как воздействовать на этот процесс с тем, чтобы повысить его эффективность” [White 1994: 872]. Несомненно, что включение прикладных технологий в состав науки принятия политических решений порождает серьезные сложности с точки зрения соотнесения их с предметами двух ранее упомянутых составных частей прикладной политологии - т.е. с предметной областью прикладного политического анализа, прежде всего в той ее части, которую называют “анализ решений” [см. Мангейм, Рич 1991], а также с проблематикой политического менеджмента, элементом которой является разработка технологий лоббирования или блокировки законодательных и административных решений. Было бы крайне трудно отгородить эти области “железным занавесом” от предметного поля теории принятия решений. Скорее всего, данные сферы в ряде случаев пересекаются, а полученные результаты и знания дополняют друг друга. Вообще, по заключению многих специалистов, для политико-управленческих дисциплин все еще характерны некоторая методологическая эклектичность и слабая организованность знаний (особенно по сравнению с такими классическими дисциплинами, как политология, экономика или социология), и они пребывают в состоянии “диффузности” (Б.Нельсон), “аморфности” (Н.Хенри) или даже “полной фрагментированности” (Д.Кеттл, М.Миног) [Nelson 1996: 566; Henry 1995: 21; Minogue 1994: 25; Kettl 1993: 407].

Два других критерия, упорядочивающих предметное поле ТППР, связаны с условным выделением “статических” и “динамических” аспектов анализа системы принятия решений, а именно внутренней структуры ее механизма и динамики процессов его функционирования и развития.

Начнем с наиболее теоретически проработанных и системно организованных исследований процессов принятия политических решений, опирающихся прежде всего на концепцию политико-управленческого цикла (policy cycle). В конце 1960-х — начале 1970-х годов в качестве реакции на ощутимый избыток “атеоретических" case studies появляется одна из первых систематических попыток построить теорию принятия решений в качестве динамического цикла, состоящего из функционально взаимосвязанных фаз управленческого процесса. В основе данного направления лежат модели функционирования политической 
системы (Д.Истон, Г.Алмонд и др.). В соответствие с этими концепциями на рубеже 1970-х — 1980-х годов некоторые ученые стали выделять такие типы политико-управленческих исследований, как, например, изучение “входов”, или общественных факторов и детерминант, государственной политики (роlicy determination, input studies), а также соответствующих еe “выходов" (studies of policy outputs), в т.ч. реальных действий правительства, их результатов и последствий для социальной среды и населения страны; так наз. анализ “содержания политики” (studies of policy content) по отдельным отраслям госуправления (образование, здравоохранение, оборона и др.) и изучение внутренних фаз управленческого процесса (studies of policy process) [Blackwell Encyclopedia 1992: 433; Gordon et al. 1997; Hogwood, Gunn 1984; Hill 1997: 2].

Итак, “динамический” критерий позволяет провести типологизацию структурных направлений ТППР в соответствии с фазами политико-управленческого цикла. На сегодняшний день в литературе выделяются три наиболее крупных таких направления: во-первых, исследования процессов формулирования и выбора проектов политических решений (policy formation/formulation studies); во-вторых, анализ осуществления данных решений в политической практике (policy implementation studies), наконец, в-третьих, изучение последствий и оценка результатов их проведения в жизнь (policy evaluation/impact studies). При этом последний, отраслевой тип явно находится на стыке фундаментальных и прикладных исследований [см. Hill 1997: 3; Sabatier 1991: 266]. В целом же изучение государственной политики как циклического процесса по сей день остается одним из самых проработанных и популярных среди специалистов по теории принятия решений.

Вместе с тем еще в 1960-1970-е годы многие исследователи обращали внимание не только на процессуальное, “динамическое”, но и на структурное, “статическое” измерение принятия решений. Линдблом призывал изучать интеракции между формальными и неформальными агентами принятия решений [cм. Lindblom 1968]. Некоторые другие ученые (Й.Гордон, Дж.Льюис и К.Янг) вообще считали тогда системно-структурное направление гораздо более перспективным по сравнению с “чрезмерно рационализированными” исследованиями политико-управленческого цикла, замечая при этом, что “анализ политико-управленческих систем (the analysis of policy systems), вероятно, самый запущенный аспект предметной области” рассматриваемой дисциплины [Gordon et al. 1977: 9]. На русском языке содержание этого второго направления ТППР максимально точно передает, наверное, выражение “изучение структуры механизма принятия политических решений”. Речь идет о весьма широкой области исследований, включающей в себя ряд подотраслей, таких как изучение политико-управленческих сетей (policy networks); проблемных комплексов (policy issues); институционально-инструментальных аспектов (policy design); влияния среды (policy environment); а также когнитивный анализ роли ценностей и знаний, норм и эмоций в принятии политических решений. Все эти относительно несхожие между собой отраслевые направления отражают, в свою очередь, крайне гетерогенные и разноплановые структурные компоненты механизма принятия решений, которые интенсивно изучаются специалистами на протяжении последних двух-трех десятилетий. В целом же структура ТППР выглядит на сегодняшний день даже более рыхлой, нежели структура политической науки_ 4 , являющейся, по заключению Г.Алмонда, “самой эклектичной” из всех социальных дисциплин и по методам, и по концептам [см. Almond 1990].

Подобная аморфность самой организации знаний о принятии решений в какой-то мере обусловлена, с одной стороны, гиперкомплексной природой изучаемого объекта, а с другой - тесной связью разрабатываемых теорий с постоянно меняющейся и усложняющейся политической практикой. Взаимодействие теоретического и практического измерений в системах государственной политики подводит современных исследователей к тройственной интерпретации феномена принятия политических решений — как искусства, как науки и как профессии (или ремесла)_ 5.

\section{Принятие политических решений как область человеческой деятельности}

Что же представляет собой принятие политических решений? В первом приближении ответ на этот вопрос дать вроде бы несложно: политологи исследуют механизмы и процессы принятия решений в рамках социальной теории, руководители накапливают практический опыт и управленческие навыки, аккумулирующиеся на том или ином уровне политического искусства. Более того, уже давно произошла профессионализация лиц, принимающих решения (ЛПР) - имеются как избираемые депутаты и должностные лица, так и назначаемые высшие администраторы и руководящие чиновники. Еще М.Вебер в свой лекции “Политика как призвание и профессия” (1918 г.) выделял, исходя из профессиональной идентификации, три политические страты: профессиональные политики, т.е. те, для которых политика является основным в материальном и духовном плане делом, отграничивались им от “политиков по случаю” 
(рядовых избирателей) и “политиков по совместительству” (скажем, партийных активистов в период выборов) [см. Вебер 1990: 652]. В обеспечении подготовки, принятия и осуществления государственных решений и заключается профессиональная деятельность так наз. политического класса.

Попробуем вначале рассмотреть вопрос о содержании принятия политических решений как “профессии” (“ремесла”). За десятилетия, прошедшие со времени прочтения Вебером его знаменитой лекции, эта сфера человеческой деятельности подверглась серьезной диверсификации и дифференциации. За минувшее столетие, наряду с традиционными профессиями руководителя (правителя), советника и чиновника, а также сформировавшимися в XIX в. профессиями парламентского депутата, политического публициста и партийного функционера или активиста, появилось множество новых политических “ремесел”. В этот период возникают профессии лоббиста и аналитика-эксперта, консультанта-технолога (прежде всего в области избирательных кампаний) и политического обозревателя электронных СМИ [см. Марков 1999: 8]. Все эти отдельные “цеха политической фабрики” объединяет то, что они так или иначе участвуют в подготовке, принятии или же проведении в жизнь каких-либо решений. Однако принадлежность к профессии в указанном измерении вовсе не сводится к наличию депутатского мандата, чиновничьего ранга или соответствующей записи в трудовой книжке, но предполагает определенного рода “профессионализм” как совокупность конкретных качеств [см. Lynn 1996: 147]. Что же в таком случае характерно для политической деятельности? В чем состоят особенности “профессионализма”?

Остановимся лишь на двух видах подобной деятельности, а именно на деятельности лиц, принимающих решения (ЛПР) в законодательных (депутаты) и исполнительных (высшие администраторы) органах власти. Какие общие профессиональные качества присущи (хотя бы в идеале) этой элите “политического класса”? Во-первых, ей нужны навыки и умения, связанные с контактами с самыми разными категориями людей и организаций, в частности коммуникативные навыки делового и публичного общения, поддержания позитивного имиджа и профессионального авторитета. Во-вторых, она должна обладать навыками аналитической и технической работы с государственными документами, законопроектами и подзаконными актами в соответствии с формальными регламентами и неформальными процедурами. В-третьих, ей требуются организационные навыки управления людьми, в т.ч. умение отстаивать и проводить “общую волю” в том или ином ее понимании, а также способность работать в коллективе. Наконец, в-четвертых, профессионализм политика и администратора заключается в строгом следовании определенным этическим и политическим принципам, которые обычно ассоциируются с положениями о целесообразности, эффективности, надежности и подотчетности обществу. Разумеется, профессиональные качества руководителя не исчерпываются умением осуществлять канцелярскую или коммуникативную работу. Согласно классификации Линдблома, профессионализм ЛПР складывается из: (а) практических технологий, которым можно заочно обучить; (б) навыков ремесла, которые приобретаются путем демонстрации в ходе непосредственного обучения, и (в) так наз. незаданной практики, т.е. собственного опыта [см. Lindblom 1981: 246]. Профессионализм лиц, принимающих ключевые решения, включает также корпоративные знания и творческие способности.

Каковы же эти знания, столь необходимые ЛПР? Ранее уже говорилось, что ТППР постепенно выделилась в сравнительно автономную научную дисциплину, опирающуюся на три типа знаний: фундаментальные, имеющие отношение к механизмам и закономерностям принятия политических решений; прикладные, касающиеся технологий и методик, и междисциплинарные, составляющие “ближний круг”, или “научную среду”, для первых двух_6 . Приведем пример. Для того чтобы подготовить тот или иной акт, скажем, в области налоговой или тарифной политики, надо обладать не только концептуальными знаниями, объясняющими структурный состав и динамику политико-управленческих сетей (фундаментальная теория), но и знанием конкретных парламентских и административных технологий, позволяющих обходить всевозможные “рифы” регламентов и процедур (прикладная область), а также специальными знаниями в области макроэкономики и финансов, выходящими за границы собственно теории принятия решений (междисциплинарная база). Иначе говоря, принятие государственных решений базируется и на рациональном анализе, и на научной оценке, и - во многих случаях — на точных математических расчетах и компьютерной обработке многообразной информации. При этом использование фундаментальных моделей дает возможность осуществлять функции описания, объяснения и предсказания, а прикладных технологий — решать задачи оценивания, предуказания и предписания.

Соответствующие знания могут формироваться двояким образом: “индуктивно”, т.е. как универсальные правила, сформулированные при обобщении позитивного практического опыта, и “дедуктивно” — как приложение к политической практике теоретических моделей, прошедших верификацию эмпирическими 
данными [см. Lynn 1996: 97]. Другими словами, в зависимости от характера практических или научных задач допустимо использовать и дескриптивно-экспликативный, и прескриптивно-нормативный подходы, а зачастую и их комбинации. Конечно же, ни один самый способный парламентарий или грамотный администратор не в состоянии самостоятельно аккумулировать такую огромную сумму знаний. Вот здесь-то и оказывается необходимой информационно-аналитическая и консультативная поддержка ЛПР со стороны специалистов (советников и экспертов) по различным вопросам государственной политики.

И все же принятие политических решений требует не только практических навыков и научных знаний. Эта область человеческой деятельности представляет собой еще и определенный вид искусства. О каком же “искусстве” идет речь? Не о таком ли, когда подчиненный в подходящий момент подсовывает на подпись своему начальнику административный акт сомнительного содержания? Или когда фракционный оратор на заседании подкомитета парламента, используя демагогические аргументы и умело влияя на эмоции депутатов, продвигает свой вариант законопроекта? Пожалуй, без определенных элементов искусства ни в первом, ни во втором случае не удалось бы добиться желаемого результата.

В чем тогда специфика искусства принимать правильные решения? Искусство составляет самую сложную для познания сторону политической деятельности, связанную с творчеством и воображением, с волей и гибкостью, с талантом и интуицией, которым должны сопутствовать предусмотрительность и выдержка, терпение и настойчивость, решительность и осторожность. ЛПР постоянно сталкиваются с нестандартными и непрограммируемыми политическими ситуациями, к которым очень трудно или даже невозможно приложить готовую модель или шаблон решения. Кроме того, решения часто принимаются в условиях дефицита времени, недостатка информации и ограниченности ресурсов [Кнорринг 1999: 24, см. также Долговых 1972]. Здесь не всегда могут помочь знания и навыки, а потому требуются креативные и интуитивные качества. Не случайно американские ученые А.Болман и Т.Дил, наряду с понятием профессионализма, вводят в свой анализ категорию “артистизм”, обозначающую релевантные для ЛПР качества восприимчивости, чуткости и многоплановости в оценке встающих перед ними проблем [см. Bolman, Deal 1991: 19].

Для того чтобы принимать решения в нестандартных ситуациях, политику требуются воображение и интуиция, сочетающиеся с рациональным аналитическим расчетом и практическим опытом. Как справедливо отмечает профессор Калифорнийского университета А.Вилдавский, специалист, анализирующий ситуацию и готовящий решение, обязательно должен обладать определенным творческим воображением, позволяющим ему проводить интеллектуальные операции по проектированию решений и их последствий, т.е. своего рода “мысленные эксперименты” [см. Wildavsky 1979: 16]. Другими словами, при принятии политических решений происходит соединение знаний (наука), навыков (профессиональное ремесло) и творчества (искусство). В такой ситуации весьма трудно разграничить между собой “сциентицизм”, “артистизм” и “профессионализм”. Отсюда следует, что принятие политических решений объединяет в себе научно-познавательную, интуитивно-творческую и рутинно-профессиональную деятельность, т.е. предполагает совмещение фундаментальных знаний с творческим воображением и интуицией, а прикладных принципов и технологий — с сугубо практическими навыками и умениями.

Аристотель. 1984. Соч. в 4-х томах. Т.4. М.

Вебер М. 1990. Избранные произведения. М.

Дегтярев А.А. 1996. Предмет и структура политической науки. - Вестник Московского университета. Сер. 12. Политические науки, № 4.

Долговых Н.Ф. 1972. Политика как наука и искусство. Дис. канд. философ. наук. М.

Клаузевиц К. 1994. О войне. М.

Кнорринг В.И. 1999. Теория, практика и искусство управления. М.

Мангейм Д., Рич Д. 1991. Анализ общественной политики и оценка программ. - Полис, № 3.

Марков С.А. 1999. Политические профессии. — Полития, № 2. 
Нойштадт Р. 1997. Президентская власть и нынешние президенты. М.

Оберемко О.А. 1994. Чикагская традиция и политическая наука Гарольда Лассуэлла. - Социологический журнал, №1.

Спиноза Б. 1998. Трактаты. М.

Стронин А.И. 1872. Политика как наука. СПб.

Чичерин Б.Н. 1898. Курс государственной науки. Часть 3. Политика. М.

Allison G. 1971. Essence of Decision. Boston.

Almond G. 1990. A Discipline Divided: Schools and Sects in Political Science. Beverly Hills.

Bolman L, Deal T. 1991. Reframing Organizations: Artistry, Choice, and Leadership. San-Francisco.

Blackwell Encyclopedia of Political Science. 1992. L.

Dror Y. 1989. Public Policymaking Reexamined. New Brunswick-Oxford.

Gordon I., Lewis J., Young K. 1977. Perspectives on Policy Analysis. — Public Administration Bulletin, № 25.

Henry N. 1995. Public Administration and Public Affairs. Atlanta.

Hill M. 1997. The Policy Process in the Modern State. L.

Hogwood B., Gunn L. 1984. Policy Analysis for the Real World. Oxford.

Kettl D. 1993. Public Administration: The State of the Field. — Finister A. (ed.) Political Science: The State of the Field. Washington.

Lasswell H. 1948. Power and Personality. N.Y.

Lasswell H. 1956. The Decision Process: Seven Categories of Functional Analysis. College Park.

Lasswell H. 1970. The Emerging Conception of the Policy Science. — Policy Sciences, №1.

Lasswell H, Lerner D. (ed.) 1951. The Policy Sciences: Recent Developments in Scope and Method. Stanford.

Lawtan A., Rose A. 1994. Organization and Management in the Public Sector. L.

Lindblom Ch. 1968. The Policy-Making Process. Englewood Cliffs.

Lindblom Ch. 1981. Comments of Decisions in Organizations. - Van de Ven H., Joyce W. (eds.) Perspectives on Organizational Design and Behavior. N.Y.

Lynn L. 1996. Public Management as Art, Science and Profession. Chatam.

Minogue M. 1994. Theory and Practice in Public Policy and Administration. — Hill M.(ed.) The Policy Process. L.

Nelson B. 1996. Public Policy and Administration: An Overview. - Goodin R., Klingemann H.-D. (eds.) New Handbook of Political Science. Oxford.

Oakeshott M. 1994. Rationalism in Politics. — McKent D., Lanton A.(eds.) Public Sector Management: Theory, Critics and Practice. L.

Sabatier P. 1991. Public Policy: Towards Better Theories of the Policy Process. — Crotty W. (ed.) Political Science: Looking to the Future. Vol. 2. Evanston. 
Simon H. 1944. Decision-Making and Administrative Organization: Part of Ph.D.Thesis. Chicago.

Simon H. 1947. Administrative Behavior: A Study of Decision-Making Process in Administrative Organizations. N.Y.

Simon H. 1960. The New Science of Management Decision. N.Y., Evanston.

Snyder R. 1958. A Decision-Making Approach to the Study of Political Phenomenon. — Young R.(ed.) Approaches to the Study of Politics. Evanston.

Sorensen T. 1963. Decision-Making in the White House: The Olive Branch and the Arrows. N.Y.

White L. 1994. Values, Ethics and Standards in Policy Analysis. — Nagel S. (ed.) Encyclopedia of Policy Studies. N.Y.

Wildavsky A. 1979. Speaking Truth to Power: The Art and Craft of Policy Analysis. Boston, Toronto.

1 늘 данный момент обращает внимание, в частности, профессор Иерусалимского университета И.Дрор, посвятивший вопросам научной институционализации теории принятия политико-управленческих решений специальную монографию [см. Dror 1989].

2_ Важно заметить, что обращение к названной проблематике характерно для мыслителей не только Запада, но и Востока. Однако эта обширная тема заслуживает отдельного разговора.

3 Кстати, сходная трактовка науки практической политики была предложена еще в конце XIX в.

Б.Н.Чичериным, который писал: “Политика есть наука о достижении государственных целей... В этом отношении она скорее подходит к характеру наук прикладных, которые отправляясь от достоверно исследованных физических законов, показывают, каким образом человек, пользуясь ими, может достигать практических целей” [Чичерин 1898: 10].

4 В то же время следует отметить, что некоторые направления ТППР, например “оценочные исследования” результатов решений (evaluation studies), выделились ныне в автономные подотрасли.

5 О п подобном разделении говорится и в трудах многих мыслителей прошлого, в частности в “Никомаховой этике” Аристотеля и “Государе” Макиавелли. На разрыв между теоретической и практической политикой обращал внимание Спиноза, писавший, что “рознь между теорией и практикой, имеющаяся во всех прикладных науках, более всего проявляется в политике; и никто не считается менее способным к управлению государством, чем философы” [Спиноза 1998: 263]. В России А.И.Стронин предлагал соединить в реальной политике теоретические конструкции с практическими знаниями, а “науку политики - дополнить политическим искусством” [Стронин 1872: 350]. Задачу разграничения “науки”, “искусства” и “ремесла” в военно-политической сфере стремился решить К.Клаузевиц, который пытался выявить основные факторы, влияющие на выбор военных решений [Клаузевиц 1994: 146].

6 Дрор разграничивает понятия “политико-управленческое знание” (policy-making knowledge), отражающее рефлексию процессов принятия решений, и “знание регулируемых проблем” (policy-issue knowledge), раскрывающее специфику объектов регулирования и отраслевых процессов [Dror 1989: 8; см. также Oakeshott 1994: 7]. 


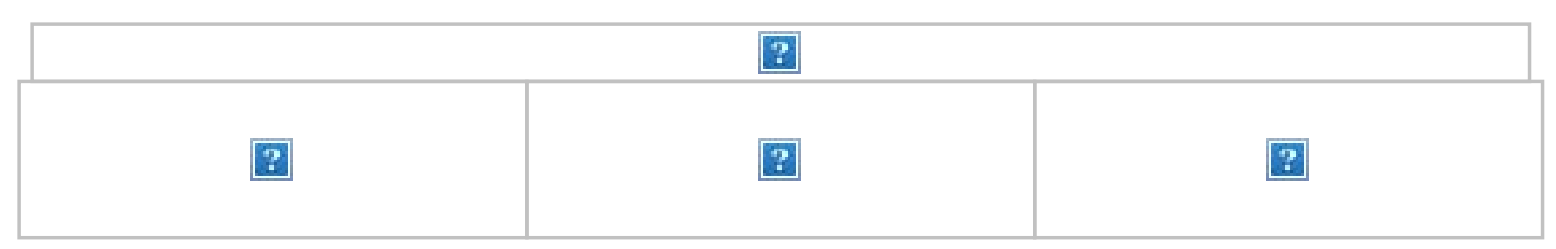

\title{
ТЕОРИЯ ПРИНЯТИЯ ПОЛИТИЧЕСКИХ РЕШЕНИЙ В СТРУКТУРЕ СОЦИАЛЬНЫХ И УПРАВЛЕНЧЕСКИХ ДИСЦИПЛИН
}

\author{
А.А. Дегтярев
}

Дегтярев Андрей Алексеевич, кандидат философских наук, профессор МГИМО (У) МИД РФ, доцент Московской школы социальных и экономических наук.

Сложилась ли теория принятия политических решений (ТППР) в самостоятельную дисциплину, каковы ее внутренняя структура и место в комплексе социальных и управленческих наук? Эти вопросы тем более актуальны, что немало специалистов считают указанное направление лишь некой междисциплинарной областью исследований. Но прежде чем подойти к ответам на них, следует, на наш взгляд, вкратце остановиться на исторических предпосылках появления ТППР и ее генезисе. Ведь многие теоретические идеи и практические принципы принятия решений были сформулированы за столетия (если не тысячелетия) до того, как рассматриваемая теория начала институционализироваться в относительно автономную сферу знания_1.

\section{Становление и развитие теории принятия политических решений}

\section{Теоретические истоки}

Вопросы принятия государственных решений, подготовки разумных законов и других актов издавна привлекали внимание философов_2_. Однако, несмотря на тот весомый вклад, который внесли в становление теории государственного управления Платон, Каутилья, Шан Ян и другие политические мыслители древности, первенство в разработке специальной концепции принятия решений все же по праву принадлежит Аристотелю. Именно он сформулировал исходный категориальный аппарат и разработал базовый концепт, описывающий принятие решений [см. Аристотель 1984: 95, 172]. В своем анализе Стагирит исходил из категорий “рассудительность” (phronesis) и “сознательный выбор” (proairesis). При этом он отталкивался от представления о том, что существуют два типа мыслительных способностей человека: теоретическая мудрость и практическая рассудительность, на которых строятся, соответственно, фундаментальное и прикладное знание. Рассудительность связана с практической деятельностью людей (в т.ч. с государственным управлением), и ей должны отвечать человеческие поступки, базирующиеся на истинных суждениях и ориентированные на достижение утилитарной пользы в форме общественного или личного блага.

Чем же рассудительность в государственном управлении отличается от прочих ее разновидностей? Политическое знание (в данном аспекте) выступает в двух ипостасях: “одна как управляющая представляет собой законодательную (науку), другая как имеющая дело с частными (вопросами) носит общее название государственной науки, причем она предполагает поступки и принимание решений, ибо что решено голосованием (народного собрания) как последняя данность (to eskhaton) осуществляется в поступках" [Аристотель 1984: 180-181]. Другими словами, принятие государственных решений основывается на практическо-политическом (т.е. прикладном, в современном понимании) типе знания, включающем в себя постановку целей (то или иное благо) и способы их реализации (поступки, действия).

Вторая базовая категория - “сознательный выбор” — отражает известную произвольность и неопределенность человеческой деятельности, направленной на поиск путей достижения уже обозначенных целей. “Предмет решения”, как отмечает Аристотель, касается не столько конечных целей, сколько средств их реализации. Поскольку человек является субъектом действий (поступков), “решение относится к тому, что он сам осуществляет в поступках, поступки же совершаются ради чего-то другого” [см. Аристотель 1984: 103]. Таким образом, принятие государственных решений, по Аристотелю, есть 
мыслительно-практическая деятельность и прикладная наука, ориентированные, во-первых, на сознательный и разумный выбор средств, адекватных сформулированным целям, а во-вторых, на выявление оптимальных и возможных действий (поступков) для достижения таких целей в условиях неопределенности ситуации и произвольности свободного выбора.

Вопросы рационального и эффективного принятия государственных решений довольно интенсивно исследовались политическими мыслителями Возрождения (Н.Макиавелли, Ж.Боден и др.) и Просвещения (Т.Гоббс, Б.Спиноза, Ж.Ж.Руссо и др.) Можно выделить ряд наиболее активно разрабатывавшихся сюжетов: виды государственных актов (Гоббс), роль советников и советов при правителях (Гоббс, Макиавелли), особенности голосования в представительных органах и народных собраниях (Спиноза, Руссо), учет ресурсов и факторов социальной обстановки при принятии решений (Боден). В работах упомянутых авторов содержится немало идей, не потерявших своей актуальности и сегодня.

Теоретическое осмысление данной проблематики, разумеется, велось и в дальнейшем. Систематический компаративный анализ достигнутого в этой области еще ждет своего научного воплощения [см. Нойштадт 1997]. В пределах, ограниченных объемом и предметом данной работы, я остановлюсь лишь на характеристике современного этапа развития рассматриваемой теории.

\section{Современный этап}

Во второй половине XX в. дифференциация социальных и гуманитарных наук продвинулась уже довольно далеко. В самостоятельную отрасль знания выделилась политическая наука, государственное управление стало преподаваться во многих западных университетах в качестве отдельной субдисциплины. Именно тогда сложились предпосылки, позволившие ТППР оформиться в особую дисциплину — теорию принятия политических решений, входящую в политико-управленческие науки (policy sciences). Последний термин был введен в 1930 - 1940-е годы одним из основателей Чикагской школы политического бихевиоризма Г.Лассуэллом. Согласно его определению, “научная дисциплина может быть отнесена к политико-управленческим наукам, если она разъясняет процесс принятия политических решений (process of policy making) в обществе или же обеспечивает необходимыми данными разработку рациональных способов разрешения политико-управленческих вопросов” [Lasswell 1948: 120].

По мнению Лассуэлла, концептуальное оформление политико-управленческих наук было в огромной мере стимулировано глубоким кризисом, связанным с двумя мировыми войнами, тем более что немалую роль в возникновении последних сыграли непродуманность и необоснованность политических решений лидеров многих держав мира [Lasswell 1948: 121]. Ученый называет и другие факторы, способствовавшие институционализации политико-управленческих наук. Прежде всего, это практические нужды сохранения и совершенствования западной демократии, требующие оптимизации государственного управления и взаимодействия органов власти с другими общественными институтами, а также интеллектуального обеспечения рационального достижения государственных целей при ограниченных ресурсах. Кроме того, внутри самих социальных наук созрела потребность в интеграции и преодолении традиционных барьеров, что позволило бы не только устранить дублирование проблематик и заполнить “белые пятна” на стыках дисциплин, но и высвободить интеллектуальные силы для приложения научных результатов к практической политике, в т.ч. к выработке долгосрочных стратегий.

Итак, во второй половине XX в. в США складывается новая область знания - политическое управление, постепенно развертывающаяся в целый комплекс политико-управленческих дисциплин. Этот сложный научный комплекс образовался на стыках предметных полей трех “кластеров” социально-гуманитарных дисциплин: (1) социально-политического (политическая, социологическая и экономическая науки); (2) когнитивно-эпистемологического (философия, психология и информационно-коммуникативные исследования) и (3) менеджериального (государственное администрирование, организационная теория, общий менеджмент, военная наука). Другими словами, произошел интеграционный синтез различных сфер социально-гуманитарного знания, к которому со временем добавились математические и кибернетические исследования и методы обработки информации. Пионерами этого междисциплинарного синтеза конца 1940 — 1950-х годов стали Г.Лассуэлл и Г.Саймон. Первый (вместе с Д.Лернером) подготовил новаторскую работу “Политико-управленческие науки” [Lasswell, Lerner 1951], второй опубликовал монографию “Административное поведение: исследование процессов принятия решений в административных организациях”, принесшую ему Нобелевскую премию [Simon 1947]. 
Какие же методологические подходы и концептуальные разработки создали предпосылки для подобной интеграции знаний в новое научное направление, в частности, для институционализации ТППР и прикладного политического анализа? Начнем с “кластера” дисциплин, связанных с социально-политическими науками. В рамках политологии импульс к изучению принятия государственных решений возник во многом вне круга традиционной для данной дисциплины проблематики. На это обращает внимание Ч.Линдблом, который замечает, что “процесс принятия политических решений не походит на такие стандартные для политической науки области, как сравнительное государствоведение, международные отношения или история политической мысли” [Lindblom 1968: 2]. Новые модели исследования государственной политики опирались главным образом на бихевиористский и системный подходы, которые начали складываться еще до второй мировой войны и изначально имели междисциплинарный характер. Прежде всего это относится к бихевиористской теории политического поведения, разрабатывавшейся Лассуэллом и содержавшей немало элементов, взятых из психологии и социологии (мотивы и установки, интересы и ценности людей, принимающих решения). Следует также напомнить, что в начале 1950-х годов вышли работы Т.Парсонса “Социальная система” (1951) и Д.Истона “Политическая система” (1953), где были сформулированы основы системно-функционального подхода к интерпретации циклов государственной политики и процессов принятия решений. Наконец, большую роль в развитии политико-управленческого анализа сыграло заимствование методов макро- и микроэкономических исследований (“затраты — выгоды”, “затраты — эффективность” и др.), активно применяющихся при оценке эффективности госрешений по сей день.

Своеобразным катализатором исследований принятия государственных решений стал когнитивно-эпистемологический “кластер”. Формирование американской концепции принятия решений проходило под воздействием философии прагматизма и инструментализма, особенно работ одного из основателей Чикагской школы, в стенах которой учились или работали Лассуэлл и Саймон, - Дж.Дьюи [см. Simon 1944, Оберемко 1994]. Именно последний был автором прагматической концепции “решения проблем” (problem solving), которая впоследствии легла в основу моделей политико-управленческого цикла (policy cycle). Кроме того, при построении теории принятия решений ее разработчики активно задействовали психологические подходы: психоаналитический (Лассуэлл) и когнитивный (Саймон). Влиянию “психологической среды” на выбор решения посвящена целая глава в уже упоминавшейся книге Саймона. В той же книге Саймон поднимает вопрос об информационном обеспечении принятия административных решений и рационализации обработки информации [см. Simon 1947].

Третий по счету (но не по значению) “кластер” дисциплин, внесших свой вклад в формирование теории принятия решений, связан с менеджериальными науками. К середине XX в. в США уже активно преподавались государственное администрирование (в школах госуправления) и курсы общего менеджмента (в школах бизнеса). В своих трудах 1940-1960-х годов Саймон последовательно обосновывал идею создания административной науки (administrative science) как универсально-общей теории принятия решений, принципы которой были бы применимы и в государственном управлении, и в руководстве бизнес-структурами [см., напр. Simon 1960]. Позднее, в 1980-1990-х годах, широкое распространение на Западе получила концепция так наз. нового госуправления (new public management), сторонники которой по сути дела исходили из близкой Саймону идеи адаптации к работе государственных органов передовых технологий, заимствованных из бизнес-менеджмента.

Существенное влияние на становление ТППР оказала организационная наука, имеющая комплексную структуру и занимающаяся теоретическими, социологическими и психологическими проблемами организаций. Эта субдисциплина начала складываться в 1930-1950-е годы главным образом в рамках корпоративного управления, а затем проникла и в государственный сектор [см. Henry 1995; Lawtan, Rose 1994]. Наконец, в аналитический арсенал рассматриваемой теории попадают активно использовавшиеся в военном управлении периода второй мировой войны методы исследования операций.

Если попытаться в общих чертах провести периодизацию пока совсем короткой истории становления современной ТППР, то, пожалуй, можно выделить три крупных этапа: (1) формирование исходных подходов и концептов (конец 1940-х — вторая половина 1960-х годов); (2) институционализация направления как университетской учебной и научной дисциплины (конец 1960-х - 1970-е годы); 3) развитие теоретических и эмпирических направлений “вширь” и “вглубь”, дифференциация и специализация направлений и подотраслей (1980-1990-е годы).

На первом этапе Лассуэлл ставит вопрос о необходимости выделения политико-управленческих наук в 
особую отрасль социального знания и публикует ряд книг, посвященных обоснованию и пропаганде этой идеи [см. Lasswell, Lerner 1951; Lasswell 1956, 1970]. В так наз. политико-управленческое движение (роlicy movement) вовлекаются многие ученые: политологи, экономисты, психологи, правоведы и др. [см. Snyder 1958, Sorensen 1963, Allison 1971]. Идет разработка подходов и обсуждение теоретических концептов. Так, на рубеже 1950-1960-х годов на страницах журнала “Public Administration Review” проводится дискуссия относительно таких моделей принятия политических решений, как “рационализм”, “инкрементализм” и “смешанное сканирование”, в которой принимают участие Саймон, Линдблом, Дрор, А.Этциони и другие известные ученые. Начинают преподаваться пробные курсы, издаваться журналы и первые учебные пособия, выходит учебник Линдблома “Процесс принятия политических решений” [Lindblom 1968]. Bce это создает определенные предпосылки для утверждения нового научного направления в качестве академической дисциплины.

В ходе второго и третьего периодов получает официальное признание ряд политико-управленческих дисциплин (“политический анализ”, “принятие политических решений” и “государственная политика”), которые включаются в программы большинства факультетов политической науки и изучаются в школах государственного администрирования. По данной проблематике защищаются сотни диссертаций, публикуются тысячи научных трудов. Постепенно складывается внутренняя специализация ученых. Создаются работы, посвященные отдельным фазам политико-управленческого цикла (формирование решения, его реализация, оценка результатов и пр.), анализу сетей в МППР, специфике принятия решений в различных сферах (в экономике, образовании, обороне и пр.). Появляется множество научных журналов по государственной политике и принятию решений, в т.ч. “Журнал политического анализа и менеджмента”. В 1972 г. создается Организация политико-управленческих исследований (Policy Studies Organization), а в 1979 г. - Ассоциация политического анализа и менеджмента (Association for Public Policy Analysis and Management), насчитывающая сегодня 80 коллективных и около 2 тыс. индивидуальных членов.

С течением времени практически полной монополии США на проведение исследований по публичной политике и ее преподавание приходит конец. Академические курсы по указанной проблематике появляются в Европе (в Великобритании, Франции, Германии, Нидерландах, странах Скандинавии и др.). Начинают выходить соответствующие журналы (например, “Journal of European Public Policy”, “Journal of Public Policy” и др.). Сегодня политико-управленческие дисциплины преподаются в высших учебных заведениях Азии, Африки, Австралии и Латинской Америки, хотя при этом “гегемония” США все же ощущается. Постепенно они проникают и в посткоммунистические страны, в т.ч. в российские университеты, где уже введены курсы по “государственной политике и управлению” и “политическому анализу и прогнозированию”.

\section{Базовые характеристики теории принятия политических решений}

\section{Предметное поле}

Попытки очертить предметное поле ТППР предпринимались с самого момента зарождения дисциплины. Обосновывая правомерность выделения политико-управленческих наук в особую отрасль социального знания, Лассуэлл следующим образом определял их предмет: “Политико-управленческие науки включают в себя: (1) методы, с помощью которых исследуется политико-управленческий процесс; (2) научные результаты исследований и (3) разработки в рамках данных дисциплин, создающие наиболее важный базис для востребованных жизнью аналитических технологий” [Lasswell 1951]_3_. Вместе с тем ученый указывал на ряд специфических черт, присущих названной совокупности дисциплин. Во-первых, эти дисциплины занимаются изучением всех фаз политико-управленческого процесса; они “имеют отношение к объяснению процесса принятия решений и исполнения решений, а также к аккумуляции данных и их интерпретации, обеспечивающих разрешение соответствующих политических проблем в определенный период” [Lasswell 1951: 14]. Во-вторых, рассматриваемый комплекс дисциплин имеет двуединую цель: с одной стороны, получение научного знания о политико-управленческом процессе как таковом, т.е. выяснение его внутренних механизмов, а с другой - накопление знаний о практическом решении реальных проблем (knowledge in the policy process), встающих перед политиками и администраторами, и выработка соответствующих рекомендаций [Lasswell 1970: 13; см. также Hill 1997: 2]. В-третьих, политико-управленческие науки ориентированы на ситуационный и комплексный анализ политической проблемы, а не на сегментированный и предметно-дифференцированный подходы. И, наконец, в-четвертых, они носят междисциплинарный и полиметодологический характер.

Множество рабочих дефиниций предмета теории принятия решений было предложено И.Дрором. Так, в 
частности, он отмечает, что политико-управленческая наука есть академическая дисциплина, ориентированная на постижение “процессов, благодаря которым и происходит воспроизводство и развитие человеческого общества и самих людей, а именно процессов и систем принятия решений, систем анализа и проектирования, а также механизмов комплексной поддержки и интеллектуального обеспечения принятия этих самых решений” [Dror 1989: 7]. При этом исследователь выделяет в ней два основных элемента: “отраслевое управленческое знание” (policy-issue knowledge), связанное с отдельными сферами управленческого воздействия (политика в области здравоохранения или, скажем, этнонациональных отношений, внешняя политика и т.д.), и собственно “знание, касающееся принятия решений” (policy-making knowledge), которое имеет дело с общими механизмами государственной политики, включая организационную структуру госаппарата, координацию операциональных взаимодействий между его подразделениями, состав управленческого персонала и, наконец, технологии обработки и анализа информации, позволяющие совершенствовать процессы управления [Dror 1989: 8].

Исходя из приведенных выше характеристик политико-управленческих наук, можно дать сводное определение предмета ТППР:

Теория принятия политических решений - это политико-управленческая наука, связанная с изучением на мультидисциплинарной основе механизмов и закономерностей публично-государственной политики, а также с разработкой принципов и методов подготовки, принятия и осуществления публично-государственных решений, составляющих политический курс, для научно-интеллектуального обеспечения эффективности государственного управления в определенных проблемных ситуациях.

Из предложенной рабочей формулировки вытекает, что ТППР имеет и фундаментальный, и прикладной аспекты, включает в себя исследования, ориентированные как на “анализ-сути-политики”, так и на “анализ-ради-политики” [см. Дегтярев 1996].

Теория принятия решений выступает своего рода связующим звеном между фундаментальным и прикладным знанием. Трудно бывает полностью отделить предварительное изучение природы и системы принятия решений, скажем, в МИД РФ, сопоставление его корпоративных традиций и ведомственных процедур с принятыми в аналогичных структурах других демократических стран (что само по себе может вменяться в задачи сравнительной политологии) от подготовки практических рекомендаций для проведения очередной модернизации аппарата данного министерства в соответствии с меняющимися условиями и задачами государственной политики. М.Хилл по этому поводу замечает, что, хотя само исследование политико-управленческого процесса считается “более фундаментальной” дисциплиной, на которую должны опираться практически ориентированные разработки в области политического анализа, было бы неверным переоценивать подобное их различие [Hill 1997: 6]. Отсюда следует, что, поскольку объект анализа в фундаментальном и прикладном исследовании принятия решений совпадает, ТППР находится на стыке фундаментальной политической теории (принятие решений в механизме власти и управления) и сравнительной политологии (сравнительные исследования публичной политики и государственного управления), с одной стороны, и прикладной политологии (политический анализ, разработка технологий политического менеджмента и управленческого воздействия) - с другой.

Какие же дисциплины подготовили базу для развития ТППР? На междисциплинарный характер этой теории еще в 1940-1960-е годы обращали внимание Саймон, Лассуэлл, Дрор и Линдблом. Выше уже говорилось, что междисциплинарный синтез знаний вокруг формировавшейся в середине XX в. теории принятия решений, включая заимствование концептов и методов разных наук, был подготовлен процессами, обусловленными становлением и распространением бихевиористского, менеджериального и системного подходов. Несколько позднее он был дополнен освоением новых методов анализа информации, связанных с внедрением кибернетического подхода и компьютерной техники. Одним из первых на эти “горизонтальные линии” интеграции указал Саймон, использовавший при конструировании своей теории административных решений элементы, взятые из психологии и экономики, политологии и социологии, организационной и информационной наук. Когда нобелевского лауреата спросили, к какой из социальных наук — к социологии или психологии - принадлежит концепция принятия решений, он ответил, что такая постановка вопроса столь же некорректна, как попытка выяснить, относится ли молекулярная биология к биологии или к химии. “В каждом из взятых случаев корректным был бы ответ: к обеим” [Simon 1997:24].

Детальный разбор вопроса о междисциплинарной основе политико-управленческого знания предпринял Дрор, выделивший 23 научные дисциплины, составляющие фундамент политического управления. Эти 
дисциплины были подразделены им на четыре группы: (а) традиционные — история, право и др.; (б) социальные - психология, социология, политическая и экономическая наука и др.; (в) новые междисциплинарные области - менеджмент, системный анализ, исследования конфликтов и коммуникаций и др.; (г) так наз. абстрактные науки - логика и семантика, философия и этика, математика и статистика [Dror 1989: 320].

Особое место в этом междисциплинарном комплексе занимает политическая наука, представляющая собой базовую площадку для синтеза всевозможных идей и подходов, концептов и методов, связанных с анализом принятия политических решений. Линдблом перечисляет ключевые вопросы, которые в ракурсе своих предметов обычно ставят представители различных наук. Психологов интересует, как человек использует свое сознание при решении проблем; экономистов - как сделать такой выбор, чтобы получить максимум выгоды; философов - каким образом человек выбирает наиболее ценное для него; специалистов по государственному администрированию - какими способами людям удается заставить целую организацию служить их целям. Обращаясь к роли политологов, которые объединяют вышеприведенные и некоторые другие вопросы в единый комплекс, Линдблом утверждает, что главным в государственной политике является вопрос о природе “политических решений” (political decisions) [Lindblom 1968: 3]. Другими словами, центральный вопрос ТППР касается отношений по поводу власти: что и как получают от тех или иных решений властвующие и подвластные, а что - общество и государство в целом? Этот ключевой вопрос политики и образует то измерение дискурса, в котором должен осуществляться междисциплинарный синтез концептов и подходов, формирующих теоретико-методологическое содержание ТППР как самостоятельной научной дисциплины.

\section{Структура}

Существует несколько критериев, на основе которых можно структурировать предметное поле ТППР. Первый из них вытекает из уже зафиксированной нами двойственности данной дисциплины, ориентированной и на познание природы и механизмов государственной политики, и на приложение этих знаний в конкретных технологиях проектирования и продвижения политических решений в практику государственного управления. Как отмечается в “Энциклопедии политико-управленческих исследований”, изучение государственной политики предполагает и фундаментальные, и прикладные исследования, которые, правда, пока еще весьма слабо связаны между собой. Это объемное “предметное поле вбирает в себя, с одной стороны, теории, описывающие и объясняющие политико-управленческий процесс, а с другой - прескриптивные теории, посвященные тому, как воздействовать на этот процесс с тем, чтобы повысить его эффективность” [White 1994: 872]. Несомненно, что включение прикладных технологий в состав науки принятия политических решений порождает серьезные сложности с точки зрения соотнесения их с предметами двух ранее упомянутых составных частей прикладной политологии - т.е. с предметной областью прикладного политического анализа, прежде всего в той ее части, которую называют “анализ решений” [см. Мангейм, Рич 1991], а также с проблематикой политического менеджмента, элементом которой является разработка технологий лоббирования или блокировки законодательных и административных решений. Было бы крайне трудно отгородить эти области “железным занавесом” от предметного поля теории принятия решений. Скорее всего, данные сферы в ряде случаев пересекаются, а полученные результаты и знания дополняют друг друга. Вообще, по заключению многих специалистов, для политико-управленческих дисциплин все еще характерны некоторая методологическая эклектичность и слабая организованность знаний (особенно по сравнению с такими классическими дисциплинами, как политология, экономика или социология), и они пребывают в состоянии “диффузности” (Б.Нельсон), “аморфности” (Н.Хенри) или даже “полной фрагментированности” (Д.Кеттл, М.Миног) [Nelson 1996: 566; Henry 1995: 21; Minogue 1994: 25; Kettl 1993: 407].

Два других критерия, упорядочивающих предметное поле ТППР, связаны с условным выделением “статических” и “динамических” аспектов анализа системы принятия решений, а именно внутренней структуры ее механизма и динамики процессов его функционирования и развития.

Начнем с наиболее теоретически проработанных и системно организованных исследований процессов принятия политических решений, опирающихся прежде всего на концепцию политико-управленческого цикла (policy cycle). В конце 1960-х — начале 1970-х годов в качестве реакции на ощутимый избыток “атеоретических" case studies появляется одна из первых систематических попыток построить теорию принятия решений в качестве динамического цикла, состоящего из функционально взаимосвязанных фаз управленческого процесса. В основе данного направления лежат модели функционирования политической 
системы (Д.Истон, Г.Алмонд и др.). В соответствие с этими концепциями на рубеже 1970-х — 1980-х годов некоторые ученые стали выделять такие типы политико-управленческих исследований, как, например, изучение “входов”, или общественных факторов и детерминант, государственной политики (роlicy determination, input studies), а также соответствующих еe “выходов" (studies of policy outputs), в т.ч. реальных действий правительства, их результатов и последствий для социальной среды и населения страны; так наз. анализ “содержания политики” (studies of policy content) по отдельным отраслям госуправления (образование, здравоохранение, оборона и др.) и изучение внутренних фаз управленческого процесса (studies of policy process) [Blackwell Encyclopedia 1992: 433; Gordon et al. 1997; Hogwood, Gunn 1984; Hill 1997: 2].

Итак, “динамический” критерий позволяет провести типологизацию структурных направлений ТППР в соответствии с фазами политико-управленческого цикла. На сегодняшний день в литературе выделяются три наиболее крупных таких направления: во-первых, исследования процессов формулирования и выбора проектов политических решений (policy formation/formulation studies); во-вторых, анализ осуществления данных решений в политической практике (policy implementation studies), наконец, в-третьих, изучение последствий и оценка результатов их проведения в жизнь (policy evaluation/impact studies). При этом последний, отраслевой тип явно находится на стыке фундаментальных и прикладных исследований [см. Hill 1997: 3; Sabatier 1991: 266]. В целом же изучение государственной политики как циклического процесса по сей день остается одним из самых проработанных и популярных среди специалистов по теории принятия решений.

Вместе с тем еще в 1960-1970-е годы многие исследователи обращали внимание не только на процессуальное, “динамическое”, но и на структурное, “статическое” измерение принятия решений. Линдблом призывал изучать интеракции между формальными и неформальными агентами принятия решений [cм. Lindblom 1968]. Некоторые другие ученые (Й.Гордон, Дж.Льюис и К.Янг) вообще считали тогда системно-структурное направление гораздо более перспективным по сравнению с “чрезмерно рационализированными” исследованиями политико-управленческого цикла, замечая при этом, что “анализ политико-управленческих систем (the analysis of policy systems), вероятно, самый запущенный аспект предметной области” рассматриваемой дисциплины [Gordon et al. 1977: 9]. На русском языке содержание этого второго направления ТППР максимально точно передает, наверное, выражение “изучение структуры механизма принятия политических решений”. Речь идет о весьма широкой области исследований, включающей в себя ряд подотраслей, таких как изучение политико-управленческих сетей (policy networks); проблемных комплексов (policy issues); институционально-инструментальных аспектов (policy design); влияния среды (policy environment); а также когнитивный анализ роли ценностей и знаний, норм и эмоций в принятии политических решений. Все эти относительно несхожие между собой отраслевые направления отражают, в свою очередь, крайне гетерогенные и разноплановые структурные компоненты механизма принятия решений, которые интенсивно изучаются специалистами на протяжении последних двух-трех десятилетий. В целом же структура ТППР выглядит на сегодняшний день даже более рыхлой, нежели структура политической науки_ 4 , являющейся, по заключению Г.Алмонда, “самой эклектичной” из всех социальных дисциплин и по методам, и по концептам [см. Almond 1990].

Подобная аморфность самой организации знаний о принятии решений в какой-то мере обусловлена, с одной стороны, гиперкомплексной природой изучаемого объекта, а с другой - тесной связью разрабатываемых теорий с постоянно меняющейся и усложняющейся политической практикой. Взаимодействие теоретического и практического измерений в системах государственной политики подводит современных исследователей к тройственной интерпретации феномена принятия политических решений — как искусства, как науки и как профессии (или ремесла)_ 5.

\section{Принятие политических решений как область человеческой деятельности}

Что же представляет собой принятие политических решений? В первом приближении ответ на этот вопрос дать вроде бы несложно: политологи исследуют механизмы и процессы принятия решений в рамках социальной теории, руководители накапливают практический опыт и управленческие навыки, аккумулирующиеся на том или ином уровне политического искусства. Более того, уже давно произошла профессионализация лиц, принимающих решения (ЛПР) - имеются как избираемые депутаты и должностные лица, так и назначаемые высшие администраторы и руководящие чиновники. Еще М.Вебер в свой лекции “Политика как призвание и профессия” (1918 г.) выделял, исходя из профессиональной идентификации, три политические страты: профессиональные политики, т.е. те, для которых политика является основным в материальном и духовном плане делом, отграничивались им от “политиков по случаю” 
(рядовых избирателей) и “политиков по совместительству” (скажем, партийных активистов в период выборов) [см. Вебер 1990: 652]. В обеспечении подготовки, принятия и осуществления государственных решений и заключается профессиональная деятельность так наз. политического класса.

Попробуем вначале рассмотреть вопрос о содержании принятия политических решений как “профессии” (“ремесла”). За десятилетия, прошедшие со времени прочтения Вебером его знаменитой лекции, эта сфера человеческой деятельности подверглась серьезной диверсификации и дифференциации. За минувшее столетие, наряду с традиционными профессиями руководителя (правителя), советника и чиновника, а также сформировавшимися в XIX в. профессиями парламентского депутата, политического публициста и партийного функционера или активиста, появилось множество новых политических “ремесел”. В этот период возникают профессии лоббиста и аналитика-эксперта, консультанта-технолога (прежде всего в области избирательных кампаний) и политического обозревателя электронных СМИ [см. Марков 1999: 8]. Все эти отдельные “цеха политической фабрики” объединяет то, что они так или иначе участвуют в подготовке, принятии или же проведении в жизнь каких-либо решений. Однако принадлежность к профессии в указанном измерении вовсе не сводится к наличию депутатского мандата, чиновничьего ранга или соответствующей записи в трудовой книжке, но предполагает определенного рода “профессионализм” как совокупность конкретных качеств [см. Lynn 1996: 147]. Что же в таком случае характерно для политической деятельности? В чем состоят особенности “профессионализма”?

Остановимся лишь на двух видах подобной деятельности, а именно на деятельности лиц, принимающих решения (ЛПР) в законодательных (депутаты) и исполнительных (высшие администраторы) органах власти. Какие общие профессиональные качества присущи (хотя бы в идеале) этой элите “политического класса”? Во-первых, ей нужны навыки и умения, связанные с контактами с самыми разными категориями людей и организаций, в частности коммуникативные навыки делового и публичного общения, поддержания позитивного имиджа и профессионального авторитета. Во-вторых, она должна обладать навыками аналитической и технической работы с государственными документами, законопроектами и подзаконными актами в соответствии с формальными регламентами и неформальными процедурами. В-третьих, ей требуются организационные навыки управления людьми, в т.ч. умение отстаивать и проводить “общую волю” в том или ином ее понимании, а также способность работать в коллективе. Наконец, в-четвертых, профессионализм политика и администратора заключается в строгом следовании определенным этическим и политическим принципам, которые обычно ассоциируются с положениями о целесообразности, эффективности, надежности и подотчетности обществу. Разумеется, профессиональные качества руководителя не исчерпываются умением осуществлять канцелярскую или коммуникативную работу. Согласно классификации Линдблома, профессионализм ЛПР складывается из: (а) практических технологий, которым можно заочно обучить; (б) навыков ремесла, которые приобретаются путем демонстрации в ходе непосредственного обучения, и (в) так наз. незаданной практики, т.е. собственного опыта [см. Lindblom 1981: 246]. Профессионализм лиц, принимающих ключевые решения, включает также корпоративные знания и творческие способности.

Каковы же эти знания, столь необходимые ЛПР? Ранее уже говорилось, что ТППР постепенно выделилась в сравнительно автономную научную дисциплину, опирающуюся на три типа знаний: фундаментальные, имеющие отношение к механизмам и закономерностям принятия политических решений; прикладные, касающиеся технологий и методик, и междисциплинарные, составляющие “ближний круг”, или “научную среду”, для первых двух_6 . Приведем пример. Для того чтобы подготовить тот или иной акт, скажем, в области налоговой или тарифной политики, надо обладать не только концептуальными знаниями, объясняющими структурный состав и динамику политико-управленческих сетей (фундаментальная теория), но и знанием конкретных парламентских и административных технологий, позволяющих обходить всевозможные “рифы” регламентов и процедур (прикладная область), а также специальными знаниями в области макроэкономики и финансов, выходящими за границы собственно теории принятия решений (междисциплинарная база). Иначе говоря, принятие государственных решений базируется и на рациональном анализе, и на научной оценке, и - во многих случаях — на точных математических расчетах и компьютерной обработке многообразной информации. При этом использование фундаментальных моделей дает возможность осуществлять функции описания, объяснения и предсказания, а прикладных технологий — решать задачи оценивания, предуказания и предписания.

Соответствующие знания могут формироваться двояким образом: “индуктивно”, т.е. как универсальные правила, сформулированные при обобщении позитивного практического опыта, и “дедуктивно” — как приложение к политической практике теоретических моделей, прошедших верификацию эмпирическими 
данными [см. Lynn 1996: 97]. Другими словами, в зависимости от характера практических или научных задач допустимо использовать и дескриптивно-экспликативный, и прескриптивно-нормативный подходы, а зачастую и их комбинации. Конечно же, ни один самый способный парламентарий или грамотный администратор не в состоянии самостоятельно аккумулировать такую огромную сумму знаний. Вот здесь-то и оказывается необходимой информационно-аналитическая и консультативная поддержка ЛПР со стороны специалистов (советников и экспертов) по различным вопросам государственной политики.

И все же принятие политических решений требует не только практических навыков и научных знаний. Эта область человеческой деятельности представляет собой еще и определенный вид искусства. О каком же “искусстве” идет речь? Не о таком ли, когда подчиненный в подходящий момент подсовывает на подпись своему начальнику административный акт сомнительного содержания? Или когда фракционный оратор на заседании подкомитета парламента, используя демагогические аргументы и умело влияя на эмоции депутатов, продвигает свой вариант законопроекта? Пожалуй, без определенных элементов искусства ни в первом, ни во втором случае не удалось бы добиться желаемого результата.

В чем тогда специфика искусства принимать правильные решения? Искусство составляет самую сложную для познания сторону политической деятельности, связанную с творчеством и воображением, с волей и гибкостью, с талантом и интуицией, которым должны сопутствовать предусмотрительность и выдержка, терпение и настойчивость, решительность и осторожность. ЛПР постоянно сталкиваются с нестандартными и непрограммируемыми политическими ситуациями, к которым очень трудно или даже невозможно приложить готовую модель или шаблон решения. Кроме того, решения часто принимаются в условиях дефицита времени, недостатка информации и ограниченности ресурсов [Кнорринг 1999: 24, см. также Долговых 1972]. Здесь не всегда могут помочь знания и навыки, а потому требуются креативные и интуитивные качества. Не случайно американские ученые А.Болман и Т.Дил, наряду с понятием профессионализма, вводят в свой анализ категорию “артистизм”, обозначающую релевантные для ЛПР качества восприимчивости, чуткости и многоплановости в оценке встающих перед ними проблем [см. Bolman, Deal 1991: 19].

Для того чтобы принимать решения в нестандартных ситуациях, политику требуются воображение и интуиция, сочетающиеся с рациональным аналитическим расчетом и практическим опытом. Как справедливо отмечает профессор Калифорнийского университета А.Вилдавский, специалист, анализирующий ситуацию и готовящий решение, обязательно должен обладать определенным творческим воображением, позволяющим ему проводить интеллектуальные операции по проектированию решений и их последствий, т.е. своего рода “мысленные эксперименты” [см. Wildavsky 1979: 16]. Другими словами, при принятии политических решений происходит соединение знаний (наука), навыков (профессиональное ремесло) и творчества (искусство). В такой ситуации весьма трудно разграничить между собой “сциентицизм”, “артистизм” и “профессионализм”. Отсюда следует, что принятие политических решений объединяет в себе научно-познавательную, интуитивно-творческую и рутинно-профессиональную деятельность, т.е. предполагает совмещение фундаментальных знаний с творческим воображением и интуицией, а прикладных принципов и технологий — с сугубо практическими навыками и умениями.

Аристотель. 1984. Соч. в 4-х томах. Т.4. М.

Вебер М. 1990. Избранные произведения. М.

Дегтярев А.А. 1996. Предмет и структура политической науки. - Вестник Московского университета. Сер. 12. Политические науки, № 4.

Долговых Н.Ф. 1972. Политика как наука и искусство. Дис. канд. философ. наук. М.

Клаузевиц К. 1994. О войне. М.

Кнорринг В.И. 1999. Теория, практика и искусство управления. М.

Мангейм Д., Рич Д. 1991. Анализ общественной политики и оценка программ. - Полис, № 3.

Марков С.А. 1999. Политические профессии. — Полития, № 2. 
Нойштадт Р. 1997. Президентская власть и нынешние президенты. М.

Оберемко О.А. 1994. Чикагская традиция и политическая наука Гарольда Лассуэлла. - Социологический журнал, №1.

Спиноза Б. 1998. Трактаты. М.

Стронин А.И. 1872. Политика как наука. СПб.

Чичерин Б.Н. 1898. Курс государственной науки. Часть 3. Политика. М.

Allison G. 1971. Essence of Decision. Boston.

Almond G. 1990. A Discipline Divided: Schools and Sects in Political Science. Beverly Hills.

Bolman L, Deal T. 1991. Reframing Organizations: Artistry, Choice, and Leadership. San-Francisco.

Blackwell Encyclopedia of Political Science. 1992. L.

Dror Y. 1989. Public Policymaking Reexamined. New Brunswick-Oxford.

Gordon I., Lewis J., Young K. 1977. Perspectives on Policy Analysis. — Public Administration Bulletin, № 25.

Henry N. 1995. Public Administration and Public Affairs. Atlanta.

Hill M. 1997. The Policy Process in the Modern State. L.

Hogwood B., Gunn L. 1984. Policy Analysis for the Real World. Oxford.

Kettl D. 1993. Public Administration: The State of the Field. — Finister A. (ed.) Political Science: The State of the Field. Washington.

Lasswell H. 1948. Power and Personality. N.Y.

Lasswell H. 1956. The Decision Process: Seven Categories of Functional Analysis. College Park.

Lasswell H. 1970. The Emerging Conception of the Policy Science. — Policy Sciences, №1.

Lasswell H, Lerner D. (ed.) 1951. The Policy Sciences: Recent Developments in Scope and Method. Stanford.

Lawtan A., Rose A. 1994. Organization and Management in the Public Sector. L.

Lindblom Ch. 1968. The Policy-Making Process. Englewood Cliffs.

Lindblom Ch. 1981. Comments of Decisions in Organizations. - Van de Ven H., Joyce W. (eds.) Perspectives on Organizational Design and Behavior. N.Y.

Lynn L. 1996. Public Management as Art, Science and Profession. Chatam.

Minogue M. 1994. Theory and Practice in Public Policy and Administration. — Hill M.(ed.) The Policy Process. L.

Nelson B. 1996. Public Policy and Administration: An Overview. - Goodin R., Klingemann H.-D. (eds.) New Handbook of Political Science. Oxford.

Oakeshott M. 1994. Rationalism in Politics. — McKent D., Lanton A.(eds.) Public Sector Management: Theory, Critics and Practice. L.

Sabatier P. 1991. Public Policy: Towards Better Theories of the Policy Process. — Crotty W. (ed.) Political Science: Looking to the Future. Vol. 2. Evanston. 
Simon H. 1944. Decision-Making and Administrative Organization: Part of Ph.D.Thesis. Chicago.

Simon H. 1947. Administrative Behavior: A Study of Decision-Making Process in Administrative Organizations. N.Y.

Simon H. 1960. The New Science of Management Decision. N.Y., Evanston.

Snyder R. 1958. A Decision-Making Approach to the Study of Political Phenomenon. — Young R.(ed.) Approaches to the Study of Politics. Evanston.

Sorensen T. 1963. Decision-Making in the White House: The Olive Branch and the Arrows. N.Y.

White L. 1994. Values, Ethics and Standards in Policy Analysis. — Nagel S. (ed.) Encyclopedia of Policy Studies. N.Y.

Wildavsky A. 1979. Speaking Truth to Power: The Art and Craft of Policy Analysis. Boston, Toronto.

1 늘 данный момент обращает внимание, в частности, профессор Иерусалимского университета И.Дрор, посвятивший вопросам научной институционализации теории принятия политико-управленческих решений специальную монографию [см. Dror 1989].

2_ Важно заметить, что обращение к названной проблематике характерно для мыслителей не только Запада, но и Востока. Однако эта обширная тема заслуживает отдельного разговора.

3 Кстати, сходная трактовка науки практической политики была предложена еще в конце XIX в.

Б.Н.Чичериным, который писал: “Политика есть наука о достижении государственных целей... В этом отношении она скорее подходит к характеру наук прикладных, которые отправляясь от достоверно исследованных физических законов, показывают, каким образом человек, пользуясь ими, может достигать практических целей” [Чичерин 1898: 10].

4 В то же время следует отметить, что некоторые направления ТППР, например “оценочные исследования” результатов решений (evaluation studies), выделились ныне в автономные подотрасли.

5 О п подобном разделении говорится и в трудах многих мыслителей прошлого, в частности в “Никомаховой этике” Аристотеля и “Государе” Макиавелли. На разрыв между теоретической и практической политикой обращал внимание Спиноза, писавший, что “рознь между теорией и практикой, имеющаяся во всех прикладных науках, более всего проявляется в политике; и никто не считается менее способным к управлению государством, чем философы” [Спиноза 1998: 263]. В России А.И.Стронин предлагал соединить в реальной политике теоретические конструкции с практическими знаниями, а “науку политики - дополнить политическим искусством” [Стронин 1872: 350]. Задачу разграничения “науки”, “искусства” и “ремесла” в военно-политической сфере стремился решить К.Клаузевиц, который пытался выявить основные факторы, влияющие на выбор военных решений [Клаузевиц 1994: 146].

6 Дрор разграничивает понятия “политико-управленческое знание” (policy-making knowledge), отражающее рефлексию процессов принятия решений, и “знание регулируемых проблем” (policy-issue knowledge), раскрывающее специфику объектов регулирования и отраслевых процессов [Dror 1989: 8; см. также Oakeshott 1994: 7]. 